\title{
RICKETTSIALPOX - A RARE BUT NOT EXTINCT DISEASE: REVIEW OF THE LITERATURE AND NEW DIRECTIONS
}

\author{
M.E. Eremeeva, K. Muniz-Rodriguez \\ Jiann-Ping Hsu College of Public Health, Georgia Southern University, Statesboro, GA, USA
}

\begin{abstract}
Rickettsialpox is an urban zoonosis caused by Rickettsia akari. To date R. akari is the only well-characterized mite-borne member of the spotted fever group. It is transmitted by the mouse mite, Liponyssoides sanguineus, commonly found on peridomestic rodents. While the disease was first discovered in New York City in 1946, a few years later a similar outbreak occurred in the Ukraine SSR. Numerous serosurveys and diagnosis of sporadic cases of rickettsialpox suggest its global distribution; however, the actual contemporary geography of rickettsialpox and its incidence are unknown. Rickettsialpox is characterized by the classic clinical triad found in rickettsioses of a black eschar, high fever, and rash but the latter is atypical as it is papulovesicular. Dermatological manifestations and the progression of rickettsialpox may mimic other infectious and noninfectious syndromes, including sexually transmitted diseases. The purpose of this review is to increase awareness of this unique disease through reanalysis of classic and contemporary clinical descriptions of rickettsialpox, evaluation of its worldwide distribution, and updates on the public health importance of the disease as well as the ecology and vector associations of $R$. akari. Our review data suggests that only limited genetic diversity exists among the available isolates of $R$. akari associated with previous outbreaks; additional effort is still required to define specific genetic markers permitting direct surveillance, accurate and reliable diagnosis, tracking and studying of the vector and host associations of contemporary isolates. The potential of $R$. akari to cross into other vector species emphasizes the necessity for detection of outbreaks of the disease in new regions of the world and in novel ecological settings. We describe existing gaps and limitations in our current understanding of the pathogenesis of rickettsialpox, the epidemiology of this disease and the genetic diversity of $R$. akari. We propose research priorities for what is needed to improve our understanding of this neglected rickettsial disease and its etiologic agent.
\end{abstract}

Key words: rickettsialpox, mite, Liponyssoides sanguineus, Rickettsia akari, rickettsiae, ecology, epidemiology.

\section{ОСПОВИДНЫЙ РИККЕТСИОЗ - РЕДКОЕ, НО НЕ ИСЧЕЗНУВШЕЕ ЗАБОЛЕВАНИЕ: ОБЗОР ЛИТЕРАТУРЫ И НОВЫЕ НАПРАВЛЕНИЯ}

Еремеева М.Е., Мунис-Родригес К.

Колледж народного здравоохранения им. Цзянн-Пин Хсу, Университет Южной Джорджии, Стейтсборо, Джорджия, США

Резюме. Осповидный риккетсиоз является городским зоонозом, вызываемым Rickettsia akari. На сегодня R. akari является единственным охарактеризованным представителем группы пятнистых лихорадок, передающихся гамазовым клещом Liponyssoides sanguineus, распространенным среди перидомических грызунов. Впервые это заболевание было описано в Нью-Йорке в 1946 г., а спустя несколько лет подобная вспышка произошла в Украинской ССР. Многочисленные серологические исследования и диагностика спорадических случаев осповид-

\author{
Адрес для переписки: \\ Еремеева Марина Евгеньевна \\ 30458, США, Джорджия, Стейтсборо, почтовый ящик 8015, \\ Университет Южной Джорджии. \\ Тел.: +1 912 478-05-04. Факс: +1 912 478-58-11. \\ E-mail: meremeeva@georgiasouthern.edu
}

\section{Библиографическое описание:}

Еремеева М.Е., Мунис-Родригес К. Осповидный риккетсиоз редкое, но не исчезнувшее заболевание: обзор литературы и новые направления // Инфекция и иммунитет. 2020. Т. 10, № 3. С. 477-485. doi: 10.15789/2220-7619-RAR-1294

(c) Eremeeva M.E., Muniz-Rodriguez K., 2020

\author{
Contacts: \\ Marina E. Eremeeva \\ Georgia Southern University PO Box 8015, Statesboro, \\ GA 30458, USA. \\ Phone: +1 912 478-05-04. Fax: +1912 478-58-11. \\ E-mail: meremeeva@georgiasouthern.edu
}

\section{Citation:}

Eremeeva M.E., Muniz-Rodriguez K. Rickettsialpox - a rare but not extinct disease: review of the literature and new directions // Russian Journal of Infection and Immunity = Infektsiya i immunitet, 2020, vol. 10, no. 3 , pp. 477-485. doi: 10.15789/2220-7619-RAR-1294

DOI: http://dx.doi.org/10.15789/2220-7619-RAR-1294 
ного риккетсиоза предполагают его повсеместное распространение на планете; однако современная география распространения осповидного риккетсиоза и уровень заболеваемости неизвестны. Осповидный риккетсиоз характеризуется классической клинической триадой в виде первичного аффекта, высокой температуры и атипичной папуловезикулезной сыпи. Дерматологические проявления и прогрессирование осповидного риккетсиоза могут напоминать другие инфекционные и неинфекционные синдромы, в том числе венерические заболевания. Настоящий обзор был нацелен на привлечение повышенного внимания в отношении этой уникальной болезни путем анализа классических и современных клинических описаний осповидного риккетсиоза, оценки его глобальной распространенности и новых взглядов на его значимость для здравоохранения, а также экологии и взаимосвязи R. akari с переносчиком. Анализ данных указывает, что среди имеющихся изолятов R. akari, выделенных в процессе предыдущих вспышек, существует лишь ограниченное генетическое разнообразие. Потребуется приложить дополнительные усилия для определения специфических генетических маркеров, позволяющих проведение эпидемиологического надзора, а также точной и надежной диагностики, отслеживания и изучения современных изолятов, переносчиков и взаимодействия с организмом хозяина. Потенциал R. akari передаваться другими переносчиками подчеркивает необходимость идентификации вспышек заболевания в неизученных регионах и в новых экологических условиях. Мы описываем существующие пробелы в современном понимании патогенеза осповидного риккетсиоза, его эпидемиологии и генетического разнообразия R. akari. Мы предлагаем перечень научных исследований, необходимых для улучшения понимания этого забытого риккетсиоза и его этиологического агента.

Ключевые слова: осповидный риккетсиоз, гамазовые клещи, Liponyssoides sanguineus, Rickettsia akari, puккетсии, экология, эпидемиология.

\section{Introduction}

At the time of its discovery, the human disease caused by Rickettsia akari was named rickettsialpox due to its clinical similarity to chickenpox and the close morphological characteristics of its etiological agent to other species of Rickettsia [34, 38, 39]. The first case of the disease was reported in June 1946 in New York City, USA where 144 individuals were diagnosed with infections manifesting with a black eschar, a high fever, and a papulovesicular rash [34]. In 1949 a large outbreak of a similar illness called vesicular rickettsiosis was reported from Ukraine [2, 4]. Subsequently, it was determined that both diseases are caused by the same etiological agent, $R$. akari, and that they share common clinical and epidemiological features, and similar ecological associations with peridomestic rodents and their mites [5]. Following its original discovery rickettsialpox received substantial attention from medical and public health professionals worldwide which then progressively diminished, possibly due to the relatively mild course of the illness and decreasing familiarity of clinicians with the disease, the availability of effective antibiotics and the broad use of pesticides for rodent control [1, 74, 75]. It was not until 2001 that widespread interest in rickettsialpox reemerged because of differential diagnostic considerations for its cutaneous lesions since the vesicular rash and later scab could lead to its misidentification as chickenpox, herpes, and/or anthrax [12, 41, 42, 58, 60, 84].

Clinical cases of rickettsialpox have been identified around the world, with the largest number of illnesses occurring in urban areas $[4,5,41,42,44,50$, $57,58,68,73,76]$; nevertheless, these largely sporadic cases do not approach the large numbers of cases diagnosed during the time of the original epidemic out- breaks in New York City and Ukraine. In the United States, rickettsialpox is not a notifiable infectious disease [16], thus its current true morbidity there is not known. It is likely rickettsialpox is similarly underrecognized in most other regions of the world.

The purpose of this review is to evaluate the available classical and contemporary information related to the eco-epidemiological and clinical features of rickettsialpox and the biological and genetic characteristics of its etiological agent, $R$. akari, in order to outline critical gaps in our contemporary understanding of this neglected rickettsiosis and to define priorities for further research studies on this neglected disease and pathogen.

\section{Rickettsia akari and its characteristics}

Rickettsia akari is an obligate intracellular bacterium in the Rickettsiaceae which shares many cellular and morphological characteristics with the core spotted fever group of rickettsiae [58]. The most recent classification based on its genetic attributes places $R$. akari in the so-called transitional group that also includes flea-borne Rickettsia felis and related organisms, Rickettsia australis, and Rickettsia hoogstraalii [31]. The genome of $R$. akari (strain Hartford CWPP) consists of a single 1,231,060-bp chromosome (GenBank accession number CP000847, with an estimated 1012 open reading frames and coding capacity of $75 \%$ ) and a 24,429 bp plasmid which is highly related to the 26,608 bp plasmid of $R$. australis [23, 24; see also "Molecular typing of $R$. akari" in the "Original articles" section of current issue, pp. 497-505]. As in other Rickettsia, the three ribosomal RNA genes have a non-canonical arrangement where the $16 \mathrm{~S}$ rRNA gene is separated from the $23 \mathrm{~S}$ 5S rRNA operon. 
The cellular structure of $R$. akari is similar to that of other species of the genus Rickettsia. Its cell wall consists of outer and inner membranes separated by a periplasmic space; the outermost surface structure forms a tetragonal capsule-like layer $[31,61]$ similar to the S-layer which was later studied morphologically in $R$. prowazekii and $R$. rickettsii $[6,77]$. Staining and visualization of $R$. akari is best achieved using the Giminez method or other protocols utilizing carbol basic fuchsin when using light microscopy or acridine orange stain or FITC conjugates with specific antibody in conjunction with fluorescence microscopy $[33,46]$.

Available isolates of $R$. akari from human, animals and mites have high levels of similarity when examined using microbiological, serological, protein and genetic tools [21, 22, 59, 68; see also "Molecular typing of R. akari" in the "Original article" section, p. 497505]. This analysis suggests that a single ancestral strain of $R$. akari was spread globally with their rodent and rodent mite hosts. The revised status of $R$. felis and its near relatives, which have proven to have a "bushy" phylogeny, suggest our sampling of relatives of $R$. akari may be far from complete [14, 51].

\section{Pathogenesis}

Similar to other Rickettsia, species R. akari infects the vascular endothelium; however, invasion of macrophages and monocytes plays significant roles in the pathogenesis of $R$. akari infection which triggers cell activation via TLR2 or TLR4 mechanisms [67, 79]. Rickettsia akari can invade cells of mammalian, arthropod and reptile origin; it enters the host cell through induced phagocytosis and induces formation of actin tails enabling intracellular movement, invasion of the host cell nucleus and cell-to-cell spread [3, 69]. Lytic plaques formed by $R$. akari in Vero cells and L929 mouse fibroblast cells are typically smaller and take longer to appear when compared to plaques formed by $R$. rickettsii and $R$. conorii [52, 81]. Rickettsia akari is tropic for human macrophages [80]; murine macrophages exhibit variable resistance to lethal effects of $R$. akari correlating with their levels of tumoricidal and antirickettsial activities [53, 54, 56]. Mouse strains with defective macrophage responses have a dominant negative mutation in the cytoplasmic domain of the TLR4 receptor, which may impact the diversity of native immune responses to this infection [35].

\section{Clinical manifestations and treatment}

Rickettsialpox is an acute illness with clinical symptoms developing after a 9 to 14 -day incubation period following the initial bite by an infected mite (summarized in [58]). Individuals infected with $R$. akari develop an initial non-itchy lesion at the site of the mite bite, which subsequently increases in size and its center transforms into a vesicle containing fluid $[34,58]$. This lesion eventually begins drying and turns into a dark eschar persisting for up to three weeks and presents as a dermal and epidermal necrosis $[4,34,41,58]$.

Clinical features of rickettsialpox include fever, chills, myalgia, headaches, and a papulovesicular rash $[4,34,41,58]$. The rash was observed in all cases reported in the literature; it persists for 4 to 7 days and typically appears on the body trunk, but it is not present on the soles or palms [2, 4, 34]. Development of the vesicular rash on the palate of the mouth is one of the specific features of rickettsialpox [19]. Additional symptoms reported in the literature include vomiting, abdominal pain, weakness, profuse sweating, fatigue, conjunctivitis, and leukopenia [2, 4, 34, 42, 50, 57, 76, 84]. Enlargement and tenderness of regional lymph nodes is common; lymphangitis has been described for some cases diagnosed in the Ukraine [4] but is commonly absent in patients from other regions. Photophobia, pain during eye movement, and nuchal rigidity were also noted in patients from Nortern Europe [73]. Hepatitis is another symptom diagnosed in several recent cases $[50,84]$. Other severe symptoms such as vaginal and gingival bleeding were reported in patients from Mexico [84]; however, it is not known at present if this specific symptomatology is due to a strain variant of $R$. akari, due to delayed diagnosis or other underlying factors responsible for enhanced susceptibility to this rickettsial infection. Most clinical cases of rickettsialpox reported in the literature recovered completely after a course of antibiotics, either tetracycline or chloramphenicol, or recovered without treatment [2, 41, 42]. Residual scarification may remain at the site of the eschar in some cases.

\section{Geographic distribution}

Rickettsialpox cases have been recorded worldwide. In the western hemisphere most of the reports originated from the United States, although this mild disease is not a nationally notifiable infectious disease in the U.S. [34, 41, 42, 44, 50, 66, 76]. The first rickettsialpox outbreak was reported in Queens, New York where 144 non-fatal cases were recorded in 1946. Four years later, in 1950, a case of rickettsialpox was identified in Boston Massachusetts in a female that had not traveled recently to New York and had no previous signs of symptoms for the disease [66], thus indicating another endemic focus of the disease existed in the USA beside New York City. Confirmation of diagnosis was made using the complement fixation test, just as in the first reports in New York City. As of July of 1952, 724 cases of rickettsialpox had been reported to the New York City Health Department [9]; occurrence of rickettsialpox was also confirmed in several other cities of the northeastern part of the USA. Only sporadic cases were identified 
in the following decades and the most western case of rickettsialpox was reported from Utah in 1961 [45].

New York City has remained the most active place for reporting and diagnosis of rickettsialpox throughout the entire history of this disease. Several reports of rickettsialpox in the Bronx, New York exist in the literature [41, 50, 76]. During 1980 to 1989, 13 cases of rickettsialpox were diagnosed at the Lincoln Hospital, Bronx, NY using indirect and direct immunofluorescence methods [41]. From 2001 to 2002, three infected female residents of Brooklyn and the Bronx had a confirmed diagnosis of rickettsialpox by IFA from serum samples and IHC from a biopsy [76]. The patients reported seeing mice in their apartment units, and one of them reported the presence of small bugs in the same area where the mice were observed [76]. Similarly, a second report of rickettsialpox in New York City described this disease as occurring predominantly in residents from the Bronx and Manhattan; there were 34 confirmed cases diagnosed using IFA, IHC, and PCR during that period [60]. In 2004, two female patients diagnosed with rickettsialpox from the Bronx, NY reported contact with mouse droppings in their work area [50]. Another United States case was in North Carolina, where the patient suggested the possibility of contact with mites at the workplace where a stray cat brought dead mice [44].

In Central America, exposure to R. akari has been reported in Costa Rica based on serological data generated using a microagglutination test; at least 3 positive serum specimens were identified in $507(0.6 \%$ prevalence) samples tested [64]. Most recently severe cases of rickettsialpox were confirmed in Yucatan, Mexico using IFA, and restriction fragment length polymorphism (RFLP) analyses of the PCR amplified DNA fragments [84]. The Yucatan cases were first suspected to be dengue fever and managed as an arbovirus infection; a pediatric patient suffering from vaginal and gingival bleeding required admission to the intensive care unit.

The distribution of rickettsialpox in the Old World spans a wider territory. More than 1000 cases were recorded in Ukraine during the original outbreak of 1949-1950 [72], but follow-up case records are not available; this disease is not reportable in the Ukraine and Russia [7]. There are also reports of serological evidence of exposure to R. akari in BosniaHerzegovina [28], Albania [11], Germany [81], and France [13]; however, no clinical case reports have been published from those countries. On the other hand, contemporary circulation of $R$. akari in Europe has been confirmed in Croatia (former Yugoslavia) [68], Turkey [57], and the Netherlands [73]. In May of 1991 the first Croatian case of rickettsialpox was diagnosed in a 36-year old male using serology and culture isolation [68]. This was the first report of $R$. akari in Western Europe with symptomatology consistent with cases reported in the United States and Ukraine with an exception that an eschar was not detected in the Croatian patient [68]. In 2003, a 9-year old boy from Turkey was believed to be infected with $R$. akari after exposure to rats on the family farm; the clinical diagnosis was confirmed by cross-absorption serological testing [57]. In July 2009, a 51-year old male was serologically diagnosed with rickettsialpox in the Netherlands [73].

Exposure to $R$. akari and occurrence of rickettsialpox has been suggested based on serological findings in several countries in Africa [30, 47, 48], including more recently in South Africa where exposure occurred for two presumed travel cases in Italian tourists [29]. Le Gac et al. (1952) described a family cluster of 16 presumed cases of rickettsialpox including 4 fatalities in members of the Baya tribe in the present Central African Republic [48]. The patients had symptomologies compatible with rickettsialpox including eschar and vesicular rash, and at least 5 out of 8 tested seroconverted to $R$. akari antigen as determined using the microagglutination method with sera collected on day 24 after onset of illness. Guinea pigs inoculated with one patient's blood developed a febrile illness and seroconverted to $R$. akari. However, the authors noticed atypical manifestations of the eschar (much larger, with deeper necrotic damages and scarification) in indigenous African patients compared to the classic description of eschars observed in patients of Caucasian and Hispanic origin [4, 34]. Since other rickettsioses than rickettsialpox are known now to occur in the same region [62], the actual etiology of this illness remains unconfirmed.

The endemicity of rickettsialpox in Korea was shown by isolation of $R$. akari from a vole in 1952 [40]. Recent evidence for circulation of $R$. akari or closely-related organism(s) in that region has come from serological and PCR findings in epidemiological and ecological survey projects [17, 18].

Follow-up studies with isolation of putative strains of $R$. akari in Central and South America, Africa and Asia are needed to determine the closeness of their relationship to strains recovered in Europe and North America.

\section{Vector-transmission and ecology}

The house mouse mite, Liponissoides sanguineus, has been recognized as a competent vector and reservoir of $R$. akari [27, 37] in which it is maintained by transovarial and transtadial transmission. The mite L. sanguineus is an opportunistic blood-sucking ectoparasite, commonly found in areas infested by rodents, such as harborages and burrows, and cracks and crevices in nearby places $[1,26,58]$. The lifecycle of L. sanguineus was described in 1954 by H.S. Fuller [26]. The eggs of mouse mites develop for 4 to 5 days, molting successively into larvae, protonymph, deutonymph, and finally the adult stage for a complete cycle in 51 to 63 days. During the egg and larval stag- 
es, mites do not take blood meals [26]. Nymphs and adult mites attach to the host and feed for 15 to 36 hours and detach upon repletion [39]; when a new blood meal is needed, the mite finds its host and bites again.

The house mouse Mus musculus is the typical urban host for the mite $L$. sanguineus [1, 2, 4, 27, 37]. House mice collected in New York City and Boston, Massachusetts had antibodies reactive to $R$. akari [27, 38], and an R. akari isolate was established from a mouse trapped in an endemic focus in Ukraine [2, $4,21]$. L. sanguineus can also feed on peridomestic rats which can also serve as an animal reservoir for $R$. akari; this has been confirmed by isolation of $R$. akari from $R$. norvegicus and $R$. rattus [2, 4, 21].

Humans get infested when natural mite rodent hosts are not available and mites are forced to cross species barriers and feed on a human host or other suitable animals [10, 43]. Severe mite infestations cause debility and anemia in rodents (cited in [80]) and may be responsible for rodent mite dermatitis in humans. The presence of mites is often first perceived during various repair and facility remodeling work that has disturbed peridomestic rodents [80] or it is associated with rodent disease-related perturbations or eradication efforts [43]. L. sanguineus were found to infest diverse laboratory rodents and rodents sold in a pet store $[49,80]$; these scenarios may pose a risk of occupational exposure for veterinarians and animal handlers. Handling suspensions of $R$. akari in laboratory settings without necessary precautions may lead to exposure and onset of infections even in individuals immune to $R$. rickettsii or $R$. prowazekii [78].

L. sanguineus can be found on a variety of wild rodents [25, 58], and may feed on large animals like cats and dogs, as suggested by detection of antibodies in the latter which were reactive with $R$. akari in California, Wisconsin and New York [8, 15, 20]. A role for dogs in the circulation of $R$. akari has been recently suggested in a report from Yucatan describing detection of $R$. akari DNA in the bloodstream of a severely ill dog and simultaneously in a tick collected from the same dog; however, there was no report of mites on the same animal [85].

The tropical rat mite, Liponyssus bacoti may acquire $R$. akari from rickettsiemic mice in an experimental setting and maintain it transovarially; however, it is not considered to be a competent vector for this pathogen despite the observations that $R$. akari may persist in the infested mite colony for at least 34 days [65]. A role for these mites in environmental maintenance of $R$. akari has not yet been demonstrated. Similarly, $R$. akari can establish a long-lasting infection of midgut and coelom of human body lice infected through rectal inoculation; this outcome is in marked contrast to the fatal infections of body lice caused by $R$. prowazekii [82]; susceptibility of human head lice to $R$. akari has not been evaluated.
Beside $L$. sanguineus, $R$. akari may have a range of vector associations as suggested by the detection of $R$. akari DNA in trombiculid mites collected from Apodemus agrarius and Crocidura lasiura in several areas of Korea [17]. The isolation of $R$. akari from the reed vole, Microtus fortis pelliceus [40] trapped in Korea in 1952 suggests the possible existence of natural cycles independent of man or commensal rodents; however, this presumption needs further evaluation. Involvement of Laelaps nuttalli (Hirst, 1915 ) in maintenance of $R$. akari was suggested during a focal outbreak of rickettsialpox in a village of L'Oubangui-Chari (present Central African Republic) where large numbers of these mites were found in wall crevices and on rodents trapped in the patient houses [48]. This mite occurs throughout the world as a parasite of the black rat, $R$. rattus, the brown rat, $R$. norvegicus and occasionally of other rodents and small mammals and is thought to harbor some pathogens typically associated with these rodents [55].

\section{Rickettsialpox: emerging issues, new directions, and public health research}

Over seventy years ago and almost simultaneously the world experienced two major outbreaks of rickettsialpox - in New York City, one of the largest metropolitan centers in the world, and in a southern city of the Ukraine. A shortage of adequate urban housing existed during and following World War II, and intimate contact between mice, their ectoparasites and man was a critical factor in these outbreaks. With lessened human population density and greater rodent control efforts, less contact between man and mice has resulted in an apparent decrease in the incidence of the disease [63]. Rickettsialpox is peculiar among known rickettsial diseases due to its urban character and mouse mite associations; however, the benign course of the illness is probably most responsible for the neglected status of this disease. The current literature confirms the continued cosmopolitan distribution of $R$. akari, L. sanguineus, and peridomestic rodents, thus suggesting that many unrecognized cases of rickettsialpox may occur. It would require a concerted effort of medical and public health staff with a focus on eschar-associated diseases and use of contemporary laboratory diagnostic methods to complete the etiological identification and characterization of disease with this organism. Such work could establish current traits of susceptible human and rodent populations and strains of $R$. akari and thus redefine the modern risk factors facilitating exposure to these organisms and better recognition of the variable clinical manifestations of rickettsialpox.

Our review data suggests that only limited genetic diversity exists among the available isolates of $R$. $a k a-$ $r i$ associated with previous outbreaks between 1948 
and 2004; however, additional effort is still required to define specific genetic markers permitting direct surveillance, tracking and studying of the vector and host associations of contemporary isolates. Use of molecular methods should be applied to survey various collections of mites beyond $L$. sanguineus to determine the true diversity of mite-associated rickettsiae and related organisms. Limited reports from Korea and China indicate that multiple species of mites may be infected with $R$. akari or $R$. akari-like organisms $[17,18,36]$ and other rickettsial agents in the USA and elsewhere [70, 71], but those findings need additional analysis, validation and interpretation using the same and/or larger sets of genes or whole genome sequences followed by making isolates and examination of their biological characteristics. Once associations of $R$. akari with other ectoparasites are established, it will be important to determine if there are wildlife reservoirs in other species for $R$. akari or related pathogens, and if disturbance of the balance of these interactions can be responsible for outbreaks of rickettsialpox-like illnesses in non-urban settings.

The identification of $R$. akari DNA and antibodies in dogs in Mexico and New York City highlights the need for increased surveillance for rickettsialpox using a One Health perspective [20, 85]. If domestic animals such as dogs can be severely affected by infection with $R$. akari, further investigations need to be targeted at the identification of $R$. akari in domestic and stray dogs, and wild canines. If commonplace infection with $R$. akari in dogs is confirmed by additional research, public health measures to examine stray dog populations should be considered by coordinating public health, veterinary and wildlife professionals. This might require a change in current prevention methods for rickettsialpox to include vector elimination from canines. The capacity of $R$. akari to cross vector species emphasizes the potential for possible detection of outbreaks of the disease in new regions of the world and in novel ecological settings. An increased awareness of rickettsialpox will require interest and enhanced effort by the scientific, public health, veterinary and medical communities or it will remain a largely neglected and largely unappreciated illness affecting an unknown number of victims.

\section{Acknowledgements}

Kamalich Muniz-Rodriguez contributed to this paper in partial fulfillment of the requirements for the Doctor of Public Health degree. We thank Gregory A. Dasch for his close reading of the paper and suggestions.

\section{Список литературы/References}

1. Киселев Р.И., Волчанецкая Г.И. Сплошная дератизация и дезинсекция как метод борьбы с заболеваемостью оспоподобным риккетсиозом // Журнал микробиологии, эпидемиологии и иммунобиологии. 1954. № 12. С. 28 -33. [Kiselev R.I., Voltchanetskaya G.I. Complete elimination of rats and mites as the means of prevention of vesicular rickettsiosis. Zhurnal mikrobiologii, epidemiologii i immunobiologii = Journal of Microbiology, Epidemiology and Immunobiology, 1955, no. 12, pp. 28-33. (In Russ.)]

2. Киселев Р.И., Жданов В.М., Александрова Н.Н. К клинико-эпидемиологической характеристике оспоподобного риккетсиоза // Сб. тр. Харьковского НИИ вакцин и сывороток имени Мечникова. 1954. Т. ХХ. С. $253-257$. [Kiselev R.I., Zhdanov V.M., Alexandrova N.N. Clinical and epidemiological characteristics of vesicular rickettsiosis. Sbornik trudov Khar'kovskogo NII vaktsin i syvorotok imeni Mechnikova = Annals of Kharkov Mechnikov Research Institute, 1954, vol. XX, pp. 253-257. (In Russ.)]

3. Кокорин И.Н., Киет Ч.Д. Прижизненные наблюдения и микросъемка внутриклеточного развития D. murinus и взаимодействие его с клетками // Журнал микробиологии, эпидемиологии и иммунобиологии. 1976. T. 5. С. 50-52. [Kokorin I.N., Kiet C.D. Vital observations and microcinematography of the intracellular development of D. murinus and its interaction with cells. Zhurnal mikrobiologii, epidemiologii i immunobiologii = Journal of Microbiology, Epidemiology and Immunobiology, 1976, no. 5, pp. 50-52. (In Russ.)]

4. Кулагин С.М. К характеристике эндемических риккетсиозов // Журнал микробиологии, эпидемиологии и иммунобиологии. 1952. Т. 12. С. 3-10. [Kulagin S.M. Characteristics of endemic rickettsiosis. Zhurnal mikrobiologii, epidemiologii i immunobiologii = Journal of Microbiology, Epidemiology and Immunobiology, 1952, no. 12, pp. 3-10. (In Russ.)]

5. Леви М.И., Киселев Р.И., Чуева Г.И., Кислякова Л.Н. К эпидемиологии везикулезного (оспоподобного) риккетсиоза. Сб. тр. Харьковского НИИ вакцин и сывороток имени Мечникова. 1954. T. XX. С. 285-291. [Levi M.I., Kiselev R.I., Tchueva G.I., Kislyakova L.N. Epidemiology of vesicular rickettsiosis. Sbornik trudov Khar'kovskogo NII vaktsin i syvorotok imeni Mechnikova $=$ Annals of Kharkov Mechnikov Research Institute, 1954, vol. XX, pp. 285-291. (In Russ.)]

6. Попов В.Л., Бархатова О.И. Взаимодействие Rickettsia akari с клеткой-хозяином in vitro: размножение, образование сферопластоподобных форм и деструкция в фаголизосомах // Журнал микробиологии, эпидемиологии и иммунобиологии. 1984. Т. 2. С. 23-27. [Popov V.L., Barkhatova O.I. Interaction of Rickettsia akari with the host cell in vitro: multiplication, formation of spheroplast-like forms and its destruction in phagolyosomes. Zhurnal mikrobiologii, epidemiologii i immunobiologii = Journal of Microbiology, Epidemiology and Immunobiology, 1984, no. 2, pp. 23-27. (In Russ.)]

7. Роспотребназор. Инфекционная заболеваемость в Российской Федерации за январь-декабрь 2018 г. [Rospotrebnadzor. Morbidity of infectious diseases in Russian Federation in January-December of 2018 (In Russ.)]

8. Bennett S.G., Comer J.A., Smith H.M., Webb J.P. Serologic evidence of a Rickettsia akari-like infection among wild-caught rodents in Orange County and humans in Los Angeles County, California. J. Vector Ecology, 2007, vol. 32, no. 2, pp. $198-201$.

9. Blattner R.J. Spread of rickettsialpox. J. Pediatr., 1953, vol. 46, no. 3, pp. 740-742. 
10. Brettman L.R., Lewin S., Holzman R.S., Goldman W.D., Marr J.S., Kechijian P., Schinella R. Rickettsialpox - report of an outbreak and a contemporary review. Medicine, 1981, vol. 60, no. 5, pp. 363-372.

11. Brezina R., Urvolgyi J., Rosicky B., Cilka S., Dushniku N., Naracik K., Dishinica G. Rickettsioses and infections caused by viruses of the psittacosis-ornithosis-mammalian pneumonia group in Albania. J. Hyg. Epid. Microbiol. Immunol., 1961, no. 5, pp. $85-88$.

12. Brouqui P., Parola P., Fournier P.E., Raoult D. Spotted fever rickettsioses in southern and eastern Europe. FEMS Immunol. Med. Microbiol., 2007, vol. 49, no. 1, pp. 2-12. doi: 10.1111/j.1574-695X.2006.00138.x

13. Brouqui P., Stein A., Dupont H.T., Gallian P., Badiaga S., Rolain J.M., Mege J.L., La Scola B., Berbis P., Raoult D. Ectoparasitism and vector-borne diseases in 930 homeless people from Marseilles. Medicine (Baltimore), 2005, vol. 84, no. 1, pp. 61-68. doi: 10.1097/01.md.0000152373.07500.6e

14. Brown L.D., Macaluso K.R. Rickettsia felis, an emerging flea-borne rickettsiosis. Curr. Trop. Med. Rep., 2016, vol. 3, pp. $27-39$. doi: 10.1007/s40475-016-0070-6

15. Case J.B., Chomel B., Nicholson W., Foley J.E. Serological survey of vector-borne zoonotic pathogens in pet cats and cats from animal shelters and feral colonies. J. Feline Med. Surg., 2006, vol. 8, no. 2, pp. 111-117. doi: 10.1016/j.jfms.2005.10.004

16. Centers for Disease Control and Prevention. National Notifiable Diseases Surveillance System, 2017 Annual Tables of Infectious Disease Data. Atlanta, GA: CDC Division of Health Informatics and Surveillance, 2018.

17. Choi Y.J., Lee E.M., Park J.M., Lee K.M., Han S.H., Kim J.K., Lee S.H., Song H.J., Choi M.S., Kim I.S., Park K.H., Jang W.J. Molecular detection of various rickettsiae in mites (Acari: Trombiculidae) in southern Jeolla Province, Korea. Microbiol. Immunol., 2007, vol. 51, no. 3, pp. 307-312. doi: 10.1111/j.1348-0421.2007.tb03912.x

18. Choi Y.J., Lee S.H., Park K.H., Koh Y.S., Lee K.H., Baik H.S., Choi M.S., Kim I.S., Jang W.J. Evaluation of PCR-based assay for diagnosis of spotted fever group rickettsiosis in human serum samples. Clin. Diagn. Lab. Immunol., 2005, vol. 12, no. 6, pp. 759-763. doi: 10.1128/CDLI.12.6.759-763.2005

19. Colman R.S. Rickettsialpox - a new rickettsial disease with oral manifestations; review of literature and case report. Oral Surg. Oral Med. Oral Pathol., 1950, vol. 3, no. 10, pp. 1257-1259. doi: 10.1016/0030-4220(50)90374-4

20. Comer J.A., Vargas M.C., Poshni I., Childs J.E. Serologic evidence of Rickettsia akari infection among dogs in a metropolitan city. J. Am. Vet. Med. Assoc., 2001, vol. 218, no. 11, pp. 1780-1782. doi: 10.2460/javma.2001.218.1780

21. Eremeeva M., Balayeva N., Ignatovich V., Raoult D. Genomic study of Rickettsia akari by pulsed-field gel electrophoresis. J. Clin. Microbiol., 1995, vol. 33, no. 11, pp. 3022-3024.

22. Eremeeva M.E., Balayeva N.M., Ignatovich V.F., Raoult D. Proteinic and genomic identification of spotted fever group rickettsiae isolated in the former USSR. J. Clin. Microbiol., 1993, vol. 31, no. 10, pp. 2625-2633.

23. Eremeeva M.E., Madan A., Halsell T., Dasch G.A. Sequencing and characterization of pRAK1, $24.4 \mathrm{~Kb}$ plasmid from Rickettsia akari. Abstract \#81. $20^{\text {th }}$ Meeting of the American Society for Rickettsiology. Colorado Springs, CO: American Society for Rickettsiology, 2007.

24. Eremeeva M.E., Madan A., Shaw C.D., Tang K., Dasch G.A. New perspectives on rickettsial evolution from new genome sequences of rickettsia, particularly R. canadensis, and Orientia tsutsugamushi. Annals of New York Academy of Sciences, 2005, vol. 1063, pp. 47-63. doi: 10.1196/annals.1355.006

25. Fuehrer H.P., Igel P., Treiber M., Baumann T.A., Riedl J., Swoboda P., Joachim A., Noedl H. Ectoparasites of livestock, dogs, and wild rodents in the Chittagong Hill Tracts in southeastern Bangladesh. Parasitol Res., 2012, vol. 111, no. 4, pp. 1867-1870. doi: 10.1007/s00436-012-2940-8

26. Fuller H.S. Studies of rickettsialpox. 3. Life cycle of the mite vector, Allodermanyssus-sanguineus. Am. J. Hyg., 1954, vol. 59, no. 2, pp. 236-239.

27. Fuller H.S., Murray E.S., Ayres J.C., Snyder J.C., Potash L. Studies of Rickettsialpox: 1: Recovery of the causative agent from house mice in Boston, Massachusetts. Am. J. Hyg., 1951, vol. 54, no. 1, pp. 82-100.

28. Gaon J., Terzin A.L. 1956. Some viral and rickettsial infections in Bosnia and Herzegovina; a sero-epidemiological study. Bull. World Health Organ., 1956, vol. 15, no. 1-2, pp. 299-316.

29. Garavelli P.L. Rickettsialpox: descrizione di due casi clinici importati dal Sud Africa. Recenti Prog Med., 2005, vol. 96, no. 12, pp. 609-610.

30. Gear J. The rickettsial diseases of Southern Africa; a review of recent studies. S. Afr. J. Clin. Sci., 1954, vol. 5, no. 3, pp. $158-175$.

31. Gillespie J.J., Williams K., Shukla M., Snyder E.E., Nordberg E.K., Ceraul S.M., Dharmanolla C., Rainey D., Soneja J., Shallom J.M., Vishnubhat N.D., Wattam R., Purkayastha, A., Czar M., Crasta O., Setubal J.C., Azad A.F., Sobral B.S. Rickettsia phylogenomics: unwinding the intricacies of obligate intracellular life. PLoS One, 2008, vol. 3, no. 4: e2018. doi: 10.1371/journal. pone.0002018

32. Gilmore R.D. Jr. Comparison of the rompA gene repeat regions of Rickettsiae reveals species-specific arrangements of individual repeating units. Gene, 1993, vol. 125, no. 1, pp. 97-102. doi: 10.1016/0378-1119(93)90752-o

33. Gimenez D.F. Staining rickettsiae in yolk-sac cultures. Stain Technol., 1964, vol. 39, pp. 135-140. doi: 10.3109/10520296409061219

34. Greenberg M., Pellitteri O., Klein I.F., Huebner R.J. Rickettsialpox: a newly recognized rickettsial disease: II. Clinical observations. J. Am. Med. Assoc., 1947, vol. 133, no. 13, pp. 901-906.

35. Hoshino K., Takeuchi O., Kawai T., Sanjo H., Ogawa T., Takeda Y., Takeda K., Akira S. Cutting edge: toll-like receptor 4 (TLR4)deficient mice are hyporesponsive to lipopolysaccharide: evidence for TLR4 as the Lps gene product. J. Immunol., 1999, vol. 162, no. 7, pp. 3749-3752.

36. Huang Y., Zhao L., Zhang Z., Liu M., Xue Z., Ma D., Sun X., Sun Y., Zhou C., Qin X., Zhu Y., Li W., Yu H., Yu X.J. Detection of a novel Rickettsia from Leptotrombidium scutellare mites (Acari: Trombiculidae) from Shandong of China. J. Med. Entomol., 2017, vol. 54, no. 3, pp. 544-549. doi: 10.1093/jme/tjw234

37. Huebner R.J., Jellison W.L., Armstrong C. Rickettsialpox: A newly recognized rickettsial disease: V. Recovery of Rickettsia akari from a house mouse (Mus musculus). Public Health Rep., 1947, vol. 62, no. 22, pp. 777-780. 
38. Huebner R.J., Jellison W.L., Charles P. Rickettsialpox: A newly recognized rickettsial disease: IV. Isolation of a Rickettsia apparently identical with the sausative agent of rickettsialpox from Allodermanyssus sanguineus, a rodent mite. Public Health Rep., 1946, vol. 61, no. 47, pp. 1677-1682.

39. Huebner R.J., Peggy S., Armstrong C. Rickettsialpox: A newly recognized rickettsial disease: I. Isolation of the etiological agent. Public Health Rep., 1946, vol. 61, no. 45, pp. 1605-1614.

40. Jackson E.B., Danauskas J.X., Coale M.C., Smadel J.E. Recovery of Rickettsia akari from the Korean reed vole Microtus fortis pelliceus. Am. J. Hyg., 1957, vol. 66, no. 3, pp. 301-308.

41. Kass E.M., Szaniawski W.K., Levy H., Leach J., Srinivasan K., Rives C. Rickettsialpox in a New York City hospital, 1980 to 1989. N. Engl. J. Med., 1994, vol. 331, no. 24, pp. 1612-1617. doi: 10.1056/NEJM199412153312403

42. Koss T., Carter E.L., Grossman M.E., Silvers D.N., Rabinowitz A.D., Singleton J. Jr., Zaki S.R., Paddock C.D. Increased detection of rickettsialpox in a New York City hospital following the anthrax outbreak of 2001: use of immunohistochemistry for the rapid confirmation of cases in an era of bioterrorism. Arch. Derm., 2003, vol. 139, no. 12, pp. 1545-1552. doi: 10.1001/archderm.139.12.1545

43. Krinsky W.L. Does epizootic lymphocytic choriomeningitis prime the pump for epidemic rickettsialpox? Rev. Infect. Dis., 1983, vol. 5, no. 6, pp. 1118-1119. doi: 10.1093/clinids/5.6.1118

44. Krusell A., Comer J.A., Sexton D.J. Rickettsialpox in North Carolina: a case report. Emerg. Infect. Dis., 2002, vol. 8, no. 7, pp. 727-728. doi: 10.3201/eid0807.010501

45. Lackman D.B. A review of information on rickettsialpox in the United States. Clin. Pediatr. (Phila.), 1963, vol. 2, no. 6, pp. 296301. doi: 10.1177/000992286300200602

46. Lauer B.A., Reller L.B., Mirrett S. Comparison of acridine orange and Gram stains for detection of microorganisms in cerebrospinal fluid and other clinical specimens. J. Clin. Microbiol., 1981, vol. 14, no. 2, pp. 201-205.

47. Le Gac P., Giroud P. Rickettsiose vesiculeuse en Oubangui-Chari (A.E.F.). Bulletin de la Societe de Pathologie Exotique et de ses Filiales, 1951, vol. 44, no. 7-8, pp. 413-415.

48. Le Gac P., Giroud P., Le Henaff A., Baup G. Epidemie familiale de rickettsiose varicelliforme dans un village de l'OubanguiChari (A.E.F.). Bulletin de la Societe de Pathologie Exotique et de ses Filiales, 1952, vol. 45, no. 1, pp. 19-23.

49. Levine J.F., Lage A.L. House mouse mites infesting laboratory rodents. Lab. Anim. Sci., 1984, vol. 34, no. 4, pp. 393-394.

50. Madison G., Kim-Schluger L., Braverman S., Nicholson W.L., Wormseri G.P. Hepatitis in association with rickettsialpox. Vector Borne Zoonotic Dis., 2008, vol. 8, no. 1, pp. 111-115. doi: 10.1089/vbz.2007.0135

51. Maina A.N., Jiang J., Luce-Fedrow A., St John H.K., Farris C.M., Richards A.L. Worldwide presence and features of flea-borne Rickettsia asembonensis. Front. Vet. Sci., 2019, vol. 5, p. 334. doi: 10.3389/fvets.2018.00334

52. McDade J.E., Stakebake J.R., Gerone P.J. Plaque assay system for several species of Rickettsia. J. Bacteriol., 1969, vol. 99, no. 3, pp. 910-912.

53. Meltzer M.S., Nacy C.A. Macrophages in resistance to rickettsial infection: susceptibility to lethal effects of Rickettsia akari infection in mouse strains with defective macrophage function. Cell. Immunol., 1980, vol. 54, no. 2, pp. 487-490. doi: 10.1016/00088749(80)90229-4

54. Meltzer M.S., Nacy C.A., Stevenson M.M., Skamene E. Macrophages in resistance to rickettsial infections: genetic analysis of susceptibility to lethal effects of Rickettsia akari infection and development of activated, cytotoxic macrophages in A and B10.a mice. J. Immunol., 1982, vol. 129, no. 4, pp. 1719-1723.

55. Montasser A.A. Redescription of female Laelaps nuttalli Hirst, 1915 (Acari: Dermanyssoidea: Laelapidae) with emphasis on its gnathosoma, sense organs and pulvilli. ISRN Parasitology, 2013: 642350. doi: 10.5402/2013/642350

56. Nacy C.A., Meltzer M.S. Macrophages in resistance to rickettsial infection: strains of mice susceptible to the lethal effects of Rickettsia akari show defective macrophage rickettsicidal activity in vitro. Infect. Immun., 1982, vol. 36, no. 3, pp. $1096-1101$.

57. Ozturk M.K., Gunes T., Kose M., Coker C., Radulovic S. Rickettsialpox in Turkey. Emerg. Infect. Dis., 2003, vol. 9, no. 11, pp. 1498-1499. doi: 10.3201/eid0911.030224

58. Paddock C.D., Eremeeva M.E. Rickettsialpox. In: Rickettsial Diseases. Eds. Parola P., Raoult D. CRC Press, 2007, pp. $63-86$.

59. Paddock C.D., Koss T., Eremeeva M.E., Dasch G.A., Zaki S.R., Sumner J.W. Isolation of Rickettsia akari from eschars of patients with rickettsialpox. Am. J. Trop. Med. Hyg., 2006, vol. 75, no. 4, pp. 732-738.

60. Paddock C.D., Zaki S.R., Koss T., Singleton J. Jr., Sumner J.W., Comer J.A., Eremeeva M.E., Dasch G.A., Cherry B., Childs J.E. Rickettsialpox in New York City: a persistent urban zoonosis. Annals of New York Academy of Sciences, 2003, vol. 990, pp. 36-44. doi: 10.1111/j.1749-6632.2003.tb07334.x

61. Palmer E.L., Martin M.L., Mallavia L. Ultrastucture of the surface of Rickettsia prowazeki and Rickettsia akari. Appl. Microbiol., 1974, vol. 28, no. 4, pp. 713-716.

62. Parola P., Paddock C.D., Socolovschi C., Labruna M.B., Mediannikov O., Kernif T., Abdad M.Y., Stenos J., Bitam I., Fournier P.E., Raoult D. Update on tick-borne rickettsioses around the world: a geographic approach. Clin. Microbiol. Rev., 2013, vol. 26, no. 4, pp. 657-702. doi: 10.1128/CMR.00032-13

63. Paterson P.Y., Taylor W. Rickettsialpox. Bull. NY Acad. Med., 1966, vol. 42, no. 7, pp. 579-587.

64. Peacock M.G., Ormsbee R.A., Johnson K.M. Rickettsioses of Central America. Am. J. Trop. Med. Hyg., 1971, vol. 20, no. 6, pp. 941-949. doi: 10.4269/ajtmh.1971.20.941

65. Philip C.B., Hughes L.E. The tropical rat mite, Liponyssus-bacoti, as an experimental vector of rickettsialpox. Am. J. Trop. Med., 1948, vol. 28, no. 5, pp. 697-705. doi: 10.4269/ajtmh.1948.s1-28.697

66. Pike G., Cohen S., Murray E.S. Rickettsialpox - report of a serologically proved case occurring in a resident of Boston. N. Engl. J. Med., 1950, vol. 243, no. 23, pp. 913-915. doi: 10.1056/NEJM195012072432304

67. Quevedo-Diaz M.A., Song C., Xiong Y., Chen H., Wahl L.M., Radulovic S., Medvedev A.E. Involvement of TLR2 and TLR4 in cell responses to Rickettsia akari. J. Leukoc. Biol., 2010, vol. 88, no. 4, pp. 675-685. doi: 10.1189/jlb.1009674

68. Radulovic S., Feng H.M., Morovic M., Djelalija B., Popov V., Crocquet-Valdes P., Walker D.H. Isolation of Rickettsia akari from a patient in a region where Mediterranean spotted fever is endemic. Clin. Infect. Dis., 1996, vol. 22, no. 2, pp. 216-220. doi: $10.1093 /$ clinids $/ 22.2 .216$ 
69. Radulovic S., Price P.W., Beier M.S., Gaywee J., Macaluso J.A., Azad A. Rickettsia-macrophage interactions: host cell responses to Rickettsia akari and Rickettsia typhi. Infect. Immun., 2002, vol. 70, no. 5, pp. 2576-2582. doi: 10.1128/iai.70.5.2576-2582.2002

70. Reeves W.K., Dowling A.P., Dasch G.A. Rickettsial agents from parasitic dermanyssoidea (Acari: Mesostigmata). Exp. Appl. Acarol., 2006, vol. 38, no. 2-3, pp. 181-188. doi: 10.1007/s10493-006-0007-1

71. Reeves W.K., Loftis A.D., Szumlas D.E., Abbassy M.M., Helmy I.M., Hanafi H.A., Dasch G.A. Rickettsial pathogens in the tropical rat mite Ornithonyssus bacoti (Acari: Macronyssidae) from Egyptian rats (Rattus spp. ). Exp. Appl. Acarol., 2007, vol. 41, no. 1-2, pp. 101-107. doi: 10.1007/s10493-006-9040-3

72. Řeháček J., Tarasevich I.V. Rickettsia akari. In: Akari-borne rickettsiae and rickettsioses in Eurasia. Ed. Gresikova M. Bratislava: Veda, Publishing House of the Slovak Academy of Sciences, 1988, pp. 128-145.

73. Renvoise A., van't Wout J.W., van der Schroeff J.G., Beersma M.F., Raoult D. A case of rickettsialpox in Northern Europe. Int. J. Infect. Dis., 2012, vol. 16, no. 3, pp. E221-E222. doi: 10.1016/j.ijid.2011.11.009

74. Rose H.M. The experimental and clinical evaluation of terramycin against Rickettsia akari (rickettsialpox). Ann. NY Acad. Sci., 1950, vol. 53, no. 2, pp. 385-394. doi: 10.1111/j.1749-6632.1950.tb42173.x

75. Rose H.M., Kneeland Y. Jr., Gibson C.D. Treatment of rickettsialpox with aureomycin. Am. J. Med., 1950, vol. 9, no. 3, pp. 300307. doi: 10.1016/0002-9343(50)90426-8

76. Saini R., Pui J.C., Burgin S. Rickettsialpox: report of three cases and a review. J. Am. Acad. Dermatol., 2004, vol. 51, no. 5, pp. S65-S70. doi: 10.1016/j.jaad.2004.03.036

77. Silverman D.J., Wisseman C.L. Jr. Comparative ultrastructural study on the cell envelopes of Rickettsia prowazekii, Rickettsia rickettsii, and Rickettsia tsutsugamushi. Infect. Immun., 1978, vol. 21, no. 3, pp. 1020-1023.

78. Sleisenger M.H., Murray E.S., Cohen S. Rickettsialpox case due to laboratory infection. Public Health Rep., 1951, vol. 66, no. 10, pp. 311-316.

79. Walker D.H., Hudnall S.D., Szaniawski W.K., Feng H.M. Monoclonal antibody-based immunohistochemical diagnosis of rickettsialpox: the macrophage is the principal target. Mod. Pathol., 1999, vol. 12, no. 5, pp. 529-533.

80. Watson J. New building, old parasite: Mesostigmatid mites - an ever-present threat to barrier facilities. ILAR J., 2008, vol. 49, no. 3, pp. 303-309. doi: 10.1093/ilar.49.3.303

81. Weber K. Serological study with rickettsial antigens in erythema chronicum migrans. Dermatologica, 1981, vol. 163, no. 6, pp. 460-467. doi: 10.1159/000250216

82. Weyer F. The behavior of Rickettsia akari in the body louse after artificial infection. Am. J. Trop. Med. Hyg., 1952, vol. 1, no. 5, pp. 809-820. doi: 10.4269/ajtmh.1952.1.809

83. Wike D.A., Tallent G., Peacock M.G., Ormsbee R.A. 1972. Studies of the rickettsial plaque assay technique. Infect. Immun., 1972, vol. 5, no. 5, pp. 715-722.

84. Zavala-Castro J.E., Zavala-Velázquez J.E., Peniche-Lara G.F., Sulú Uicab J.E. Human Rickettsialpox, Southeastern Mexico. Emerg. Infect. Dis., 2009, vol. 15, no. 10, pp. 1665-1667. doi: 10.3201/eid1510.081507

85. Zavala-Castro J.E., Zavala-Velazquez J.E., del Rosario Garcia M., Arias Leon J.J., Dzul-Rosado K.R. A dog naturally infected with Rickettsia akari in Yucatan, Mexico. Vector Borne Zoonotic Dis., 2009, vol. 9, no. 3, pp. 345-347. doi: 10.1089/vbz.2008.0189

\section{Авторы:}

Еремеева М.Е., д.б.н., профессор, зав. лабораторией, Колледж народного здравоохранения им. Цзянн-Пин Хсу, Университет Южной Джорджии, Джорджия, Стейтсборо, США; Мунис-Родригес К., магистр общественного здравоохранения, аспирант, Университет Южной Джорджии, Джорджия, Стейтсборо, США.

\section{Authors:}

Eremeeva M.E., PhD, MD (Biochemistry), Professor, Laboratory Director, Jiann-Ping Hsu College of Public Health, Georgia Southern University, Statesboro, GA, USA;

Muniz-Rodriguez K., MPH, Graduate Student, Georgia Southern University, Statesboro, GA, USA. 